International Review of Social History 44 (1999), Supplement, pp. 33-52

(C) 1999 Internationaal Instituut voor Sociale Geschiedenis

\title{
Narratives Serially Constructed and Lived: Ethnicity in Cross-Gender Strikes I887-1903*
}

\author{
ILEEN A. DEVAULT
}

On I August I893, already feeling the pinch of economic downturn, management at the Pray, Small \& Co. shoe factory in Auburn, Maine, posted new

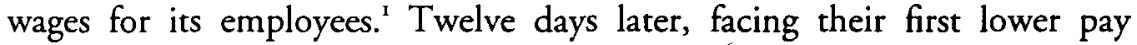
checks, female stitchers in the factory walked off their jobs. The union which represented the stitchers declared the shop non-union a week later and called for all of its members to join the stitchers' strike. Only about a dozen male workers answered this call, as the two most highly-skilled groups of male workers, the lasters and the shoe cutters, remained on the job. These workers belonged to their own separate unions, which had either already agreed to the new wage list (the cutters) or were in the middle of negotiations over it with the company (the lasters). It took the cutters another week before they decided to join the stitchers' action; it would take the lasters a month and a half and a citywide expansion of the strike to make the same decision.

Once the lasters joined the strike, however, their employers lost no time in bringing in recent immigrants from Armenia to replace the striking lasters. Strikers similarly lost no time in their response, firing off both letters to their congressmen and bricks and stones at the hapless Armenians. The strikers, who had appeared to be almost hopelessly divided by gender and skill at the beginning of August, found themselves in early October united as "honest American workmen" [sic] against "the pauper labor of Europe".

The Auburn strike highlights both the gender and the ethnic identifications of these members of the working class and encourages us to begin to think about the complex relationships among class, gender, and ethnicity. How did the Auburn workers view their participation in the strike of 1893 ? Did the stitchers view themselves as women, as well as workers? How selfconscious was the identification of the curters and lasters as men and male breadwinners? Did the introduction of Armenian strikebreakers congeal the strikers' identities as "Yankees" or simply as non-Armenians? How can the

\footnotetext{
* My thanks to the editors of this supplement, Eileen Boris and Angélique Janssens, as well as to Jeanne Boydston, Marjorie DeVault, Lori Ginzberg, Michael Lounsbury, and Roey Thorpe for their comments.

I. Unless otherwise noted, the story of this strike comes from coverage in the Lewiston Evening Journal (hereafter cited as LEJ), the Boston Globe, and the Shoe and Leather Reporter, vol. 56 (hereafter cited as $S L R$ ).

2. $S L R, 5$ October 1893 (vol. 56, no. 14), p. 798.
} 
historian begin to untangle these conflicting possible identifications, all brought to surface in this ultimate expression of class - the strike?

Unfortunately, available sources do not permit complete answers to any of these questions. Newspaper accounts of the strike provide only snippets of the strikers' own words, combined with incomplete coverage of their actions. At best, both the newspapers and the scattered extant union reports only provide observers' views and opinions of the strike, its events, and its participants. These and other sources, however, do present some sense of the actions taken by some strikers and they facilitate understanding the identities assigned to the strikers by others and against which the strikers would develop their own consciousnesses.

Even without such problematic sources, the historian is left with only the sketchiest of answers to questions of intent and cognizance. Use of the Sartrian concept of seriality can begin to overcome this problem and start to untangle the knotty problems of workers' identifications and consciousness. ${ }^{3}$ This essay will argue that class, gender, and ethnicity are "serial" in two senses of that term. One is Sartre's philosophical sense of such categories as serial, of individuals' consciousness of belonging to such categories in effect waiting to be ignited by external events and then acted upon by the individuals in question. The other is the more ordinary sense of events being serial, of their occurring one after another - in other words, the standard understanding of historical narrative. My goal is to overlay these two senses of the ways in which individuals' identifications are serial.

For Sartre, a series was a collection of individuals defined as such by their basic orientation toward and relationship to material structures. (His illustration begins with individuals waiting for a bus in the morning.) From outside the series, observers may see these individuals as having certain characteristics in common, but the members of the series do not necessarily see themselves as having anything in common. Their commonality only exists in relation to the bus and its route. If something happens (such as the bus passing them by) to make them aware of themselves and each other as having something in common (they may all be late for work now), they may acknowledge their commonality, for example, through conversation. At this point, Sartre argues that the series becomes a group. In this way, any individual is, at any given time, a member of many different series, a potential member of many different groups. It is only when these individuals begin to take action (perhaps combining to take a taxi to work) that their group becomes a fused group. If this group were to organize a boycott of the

3. See Iris M. Young, "Gender as Seriality: Thinking about Women as a Social Collective", Signs, I9 (1994); Sonya Rose, "Class Formation and the Quintessential Worker", in John Hall (ed.), Reworking Class (Ithaca, NY, 1997); and Jean-Paul Sartre, Critique of Dialectical Reason (London, 1976), esp. vol. I, book I, ch. 4 and book 2, chs I, 2, 6, and 7. In what follows, when I refer to Sartre's use of terms such as "serial", I will put them in italics. When this word, or others appear not italicized, then I am using them in their ordinary English usage. 
bus, they would become a pledged group. Sartre, whose interest was in discussing the significance of a "working class", then considers the ways in which these fused and pledged groups might be formalized as institutions. (His analysis, formulated in the 1950s, focused particularly on what he called ossified institutions, a clear reference to the bureaucratized unions of the I940s and 'sos.)

Iris Young has argued that Sartre's concept of seriality provides us with a useful way of thinking about women, allowing us to account for women whose experiences may vary widely depending on their race, ethnicity, social class, and other factors. As Young puts it, "Gender, like class, is a vast, multifaceted, layered, complex, and overlapping set of structures and objects. Women are the individuals who are positioned as feminine by the activities surrounding those structures and objects. ${ }^{n}$ The many structures determining the series of women include the socially constructed sexual division of labor in the workforce. Race and nationality could also be seen as a form of seriality, though Young does not discuss the ways in which these might function.

Like Young, I borrow freely these useful concepts from Sartre's work. For my purposes, the use of Sartre's concept of seriality translates into the following pattern: a strike begins at the moment when individual workers (in the series, "workers in X plant") come together and recognize that they have interests, needs, or desires in common which are in opposition to those of their employer (thereby forming a group). They collectively stop work (becoming a fused group). At this point, some of these workers may form a union (a pledged group) or attempt to utilize an existing union (an institution) in order to sustain their struggle. The moment of a strike's inception - that moment when workers as a collective put down their tools and stop working - demonstrates the coalescence of the series into the group which we can recognize as exhibiting incipient working-class identity. This moment of incipient class crystallization, however, is difficult to sustain. Individual workers' identifications with other series to which they belong often rise to the surface, especially during extended strikes. Gender, ethnicity, race, religion, and family status are only a few of the possible examples of the social markers of such series. Some of these markers subsequently become encoded in workers' union organizations, or institutions. ${ }^{5}$

While my focus on strike activities leads to a certain privileging of class over other categories, here my interest is not so much in the strike itself as an expression of class but in the ways in which a strike situation heightens

4. Young, "Gender as Seriality", p. 728.

5. The further comprehension of such an encoding of genders into unions belonging to the early AFL is the goal of my larger study, tentatively titled United Apart: Sex, Gender, and the Rise of Craft Unionism (forthcoming, Cornell University Press). See also my essay, "'To Sit Among Men': Skill, Gender, and Craft Unionism in the Early American Federation of Labor", in Eric Arnesen, Julia Greene, and Bruce Laurie (eds), Labor Histories: Class, Politics, and the Working-Class Experience (Chicago, IL, 1998). 
and highlights the many points of tension and division which normally operate below the surface of workers' daily lives. Rick Fantasia has examined contemporary strikes in a similar manner, calling on Lloyd Warner's discussion of the strike as a crisis in which people have to make fundamental decisions about their lives and livelihoods. ${ }^{6}$ Strikes not only highlight the class or economic components of workers' lives, but also bring to the surface the fracture lines disrupting so-called "pure" class consciousness. My concern lies in the ways in which a strike serially leads workers to confront the significance of different series to which they may belong.

Thinking about workers' identifications in this serial/serial way does away with questions of whether any one of the categories (i.e., class, race, gender, ethnicity) is dominant over the others. Instead, the use of Sartre's concept underscores that every individual at every moment holds within herself a simultaneous range of possible identities. Which of these identities will enter the consciousness of this individual and therefore inform her actions at any particular point in time depends on her role in the ongoing historical narrative, or serial.

This way of conceptualizing the issue keeps alive the basic concepts of historical materialism. Workers do not act randomly; their actions in fact grow out of the material circumstances of their lives. (In this case, those material circumstances arise at the conjuncture of their positions within given workplace and family divisions of labor.) At the same time, using Sartre's concept of a series keeps alive the idea of individual workers' agency as well, since the worker retains the ability to decide whether or not to act out of any given serial membership at any moment. It is only within the actual twists and turns of the historical narrative that we can begin to understand the shifting contingencies of specific situations. In turn, these contingencies endow historical actors with the power of agency. The strike stories narrated below show the operation of the complexities possible in the interaction of historical narrative, historical materialism, and individuals' agency.

All of the strikes under consideration involve workforces divided deeply and fundamentally by sex. As we will see, all the industries involved depended on relatively elaborate sexual divisions of labor. ${ }^{7}$ Because of this, gender was a frequent social marker around which group consciousness developed within the class-driven dynamics of these strikes. Yet gender and ethnicity, as series, both coexist and serially surmount one another. What follows presents four stories of strikes in which gender and ethnicity are interwoven in different ways. The strike of shoe workers in Auburn, Maine, illustrates the ways in which incipient gender divisions could be overcome

6. See Rick Fantasia, Cultures of Solidarity: Consciousness, Action, and Contemporary American Workers (Berkeley, CA, 1988), p. I6.

7. United Apart examines strikes in four broad industries: boots and shoes, clothing, textiles, and tobacco products. All but tobacco products are represented in the narratives given in this paper. 
by the introduction of strikebreakers defined as an ethnic "other". The next strike, that of New Jersey thread workers, exemplifies the reinforcement of deep gender divisions by equally deep ethnic divisions among the workers. A strike of Baltimore garment workers demonstrates the ways in which ethnic ties among workers could overcome gender divisions, an outcome cemented by the presence of an ethnic "other" in the industry. Finally, a strike of Wilkes-Barre, Pennsylvania, lace workers reveals how both gender and ethnic divisions could be muted by workers' family positions and community relationships.

In all of these strikes, workers' multiple positions in relation to material structures both limit and expand their agency within their particular historical narrative. As we have already begun to note in the Auburn strike, different patterns of gender and ethnicity are not necessarily mutually exclusive. Rather, as the strike narratives proceed, we see how these different interactions of gender and ethnicity can be realized both serially and serially, in sequence. Following these types of interactions through historical narrative avoids static categories and allows us to witness instead the flux and contingency of actors' identifications along lines of class, gender, and ethnicity.

With this in mind, then, let us return to the Auburn strike, this time in a bit more detail. The workforce at Pray, Small \& Co., like that at other shoe factories throughout New England, was highly segregated by sex. Male "cutters" cut out the leather pieces for the shoes; female "stitchers" used specialized sewing machines to sew the pieces together, make buttonholes in them, and add decorative stitching; male "lasters" shaped the leather upper to the sole in order to size the shoe; and male "bottomers" did the final fastening together of the shoe. By the I89os the long history of the sexual division of labor in shoe production ensured that the workplaces of New England shoe workers as well as their unions were stratified by sex. ${ }^{8}$

For almost two weeks after the posting of new wages on I August, Pray, Small's female stitchers presumably discussed the proposed changes. It is easy to imagine the groans at the initial announcement of wage cuts, followed by increasingly animated discussion of the burdens the cuts would place on them and their families. Here we see the stitchers initially acting out of their sense of membership in a series, that of stitchers at Pray, Small. On Saturday 12 August they walked off their jobs, refusing to work for the lower wages. The union representing the stitchers, Local 12 of the Boot and 
Shoe Workers' International Union (BSWIU), then convened meetings of both the striking stitchers and of the non-striking male workers in the factory. For the first week of the strike, male workers continued at their jobs even though only a handful of women remained in the stitching room. Without the labor of the stitchers, however, shoes remained unfinished. As negotiations with the company ground to a halt, the shoe workers' union declared the shop non-union and announced that all workers would join the stitchers' strike. Now some male workers, too, would be acting out of their membership in a larger series, that of Pray, Small employees.

Though more workers joined the strike on Monday 2I August, neither the lasters belonging to the Lasters' Protective Union (LPU) nor the shoe cutters of the Boot \& Shoe Cutters' Union (BSCU), responded to strikers' appeals for solidarity. The cutters already had reached agreement with Pray, Small on the new wages, and the lasters were still negotiating with the company. For both these groups of skilled male workers, their membership in their own series of skilled workers still outweighed their identities as members of the series, Pray, Small employees. This soon changed for the cutters, however, who, despite their prior agreement with management on wages, on Friday 25 August "packed their traps and left the shop". Firm officials rightly "supposed [that the cutters' walkout] was because of the trouble in the stitching room ${ }^{\prime 9}$ Cutters now joined the group of strikers at Pray, Small.

The following Monday, 28 August, the Auburn Manufacturers' Association, with which Pray, Small, and Co.'s management had been conferring throughout the past two weeks, escalated the stakes. The seven shoe companies belonging to the association told their cutters and stitchers that they would not be needed after the following Saturday. By this action, the shoe companies announced their "intention [...] to run free shops in the future", in other words, not to recognize union contracts. ${ }^{10}$ This action by the manufacturers made all Auburn's shoe workers aware of their status as members of the series, shoe workers. In the light of the manufacturers' actions, Auburn shoe workers held a mass meeting, featuring a two-hour-long speech by Henry J. Skeffington, national secretary of the BSWIU. The meeting ended with an "enthusiastic" vote for arbitration of the current dispute. ${ }^{\text {II }}$ Virtually all of Auburn's shoe workers could now see themselves as and act out of their membership in a common series.

The following Monday was Labor Day and Auburn shoe workers participated in both city and state parades. In both, they acknowledged the industry's division of labor and their own understanding of the different series they belonged to, as cutters, lasters, and other male shoe workers each marched separately, while "lady" shoe workers rode in carriages.

9. LEJ, 25 August 1893 , p. 7 .

10. $S L R$, 31 August 1893 (vol. 56.9), p. 493.

II. $L E J, 29$ August 1893, p. 5 . 
After Labor Day, the seven shoe employers of the Auburn Association announced that all of their workers - except lasters - would now sign "individual contracts", and agreements with the workers' unions would no longer be recognized. Manufacturers gave workers until noon on Tuesday September ig to sign the individual contracts.

The workers responded by declaring through their unions (BSWIU Local I2 and BSCU Local 164) that:

Believing in our right to organize for our mutual benefit, and having taken the solemn obligations of our respective unions, we firmly declare that we will fight this issue to the bitter end, at all times ready to hold to our agreements, submit to arbitration all difficulties arising between our employers and ourselves, and that is what we most desire to do on the question of adjusting prices in the stitching room the Pray, Small Company. ${ }^{\mathrm{T}}$

All the female stitchers and most of the town's male shoe workers were now united in their fight against the employers.

Auburn lasters, in the meantime, had thus far declined to join the job actions, identifying themselves more as members of their pledged group, their union, than as members of the larger series of shoe workers in general. Just before Labor Day, union lasters at the Pray, Small Company had agreed to the company's proposed wages for the next year. By the following week, these same lasters also had no reason to work in the Association shops due to their reduced workforces. On Saturday 22 September one of the shops told their lasters to return to work. The lasters refused, calling it "an unreasonable demand [...] done simply as a test". Declaring that "for them to last shoes which are turned out by non-union men they would be false to their fellow workmen", the lasters met later that afternoon and voted to stop work and "remove their jacks from the shops" on Monday morning. ${ }^{13}$

At noon on Monday 25 September some 300 to 400 lasters gathered at the Lasters' Union Hall in Auburn. After an hour and a half of discussion and debate, they "came out and marched in squads to their respective shops after their kits". Other shoe workers cheered the lasters' decision, and an officer of the BSWIU asserted that: "We have feared that the lasters were going to let us fight on single handed. Their action has given us both strength and courage. ${ }^{{ }_{14}}$ The manufacturers retorted that the lasters had now broken their contract. The lasters responded that they had not broken their contract and "that the manufacturers intended to haul them over the coals from the very beginning. 'Their aim was to break our union along with the rest', said a prominent member of the Lasters' Union. ${ }^{15}$

The action of the lasters signaled a new phase of the strike. The most

12. $L E J, 16$ September 1893 , p. 16.

13. LEJ, 23 September 1893, p. 7; Boston Globe, 24 September 1893, p. 7.

14. $L E J, 25$ September 1893 , p. 7.

15. LEJ, 26 September 1893, p. 7. 
skilled male workers in the shoe shops, the lasters had remained carefully aloof up to this point. Their decision to walk out meant that any continuing work in the shops ground to a halt, whatever the employers might say. Finally, the lasters acknowledged their membership in the larger series of Auburn shoeworkers, and thus joined the strikers. The manufacturers, for their part, vowed to continue production. The Shoe and Leather Reporter now prophesied a "long and bitter" conflict and reported that "the manufacturers feel that they must carry their point or there will be no peace for them in the futuren ${ }^{16}$

Less than a week after the lasters entered into the fray, reports reached strikers that the shoe companies were planning to bring in immigrant labor - either Italian or Armenian - to replace the now-striking lasters. When a dozen Armenian lasters arrived in town and began working in the factories on Saturday 30 September all hell broke loose. Ethnicity, as much as gender or strike status, became the basis for series identification. Nonimmigrant strikebreakers brought into town that day were met by union members, who took them out to dinner and then to the local union hall. Armenians, on the other hand, were greeted by crowds of stone-throwing strikers and their supporters. Strikers accused Armenians of responding with firearms and knives. Over the following week, physical conflict between the Armenian strikebreakers (said to number two dozen by the week's end) and crowds including "hundreds of women and children" continued whenever the Armenians ventured outside of their hotels or boarding houses. For a brief time, ethnic identifications superseded all others, both among the selfstyled "Yankee" strikers (many of whom were themselves immigrants from both French and British Canada) and among the Armenians, who were reminded of their membership in the two series, that of "Armenians" and that of "scabs", every time they poked their noses out of the door and were met with the shouts, bricks, and bats of the strikers. At this point, gender virtually disappears as a salient series of identity; both male and female strikers battled Armenian strikebreakers in Auburn's streets.

In addition to their direct action against the Armenian strikebreakers, the Auburn strikers and their unions appealed to their Congressional representatives for relief from immigrant competition. Union leader Skeffington accused Auburn manufacturers of trying "to fill the places of their Yankee employees with the imported offscouring of Europe". Within a week, Armenian communities in Massachusetts had become concerned enough about the situation to send representatives to Auburn to attempt to quiet down the situation. The goal of the Armenian "Hentchakist" (or "Hentsharkist") party of Lynn in doing this was clearly stated as being "to 
assist the union with their utmost efforts" ${ }^{17}$ One of the representatives sent was quoted by a Boston newspaper as saying that the approximately 7,000 Armenians in the US "believe in unions, and think their countrymen should keep away from places where strikes are on ${ }^{78}{ }^{18}$

The arrival of the Armenian Hentchakists seems to have quieted down the anti-Armenian hysteria in Auburn. By Sunday 8 October rumor had it that "the Armenian shoemakers were leaving the shops and going back where they came from". (Presumably in the US, not Armenia!) ${ }^{19}$ By this time, too, strikers in Auburn had new worries with which to concern themselves. On 5 October the first of several injunctions was granted in the Supreme Court against leaders and activists of the shoe workers' unions. Though the strikers remained suspicious of the national origins of later strikebreakers, in general the legal battles now took precedence.

Once the injunctions moved the Auburn struggle from the streets into the courtroom, two things happened. First of all, the legal battles were taken over more and more by the national unions and their leaders. As control of events slipped out of local workers' hands, enthusiasm for the strike waned. Secondly, manufacturing began to resume, albeit slowly, in the city's shoe factories. By February 1894, though the strike was still officially in place, some 500 of the original 2,000 to 3,000 strikers had returned to work. ${ }^{20}$ Many more workers had been replaced by this point, and most of the original strikers joined the swelling ranks of the unemployed at the beginning of the 1890 os depression. The strike which women stitchers had begun so enthusiastically in August would dwindle away, remaining a reality only in the boycott lists of the AFL and in the continued unemployment of many of the strikers. ${ }^{21}$

The narrative of the Auburn strike suggests one role ethnicity might play in a strike situation. Other strikes give us different scenarios, and therefore

17. LEJ, 5 October 1893 , p. 5. Spelling aside, this may be a reference to the Social-Democratic Hnchagian Party, founded in 1887. See Robert Mirak, Torn Between Two Lands: Armenians in America, I890 to World War I (Cambridge, MA, 1983), pp. 88-89, 207-209.

18. Boston Globe, 7 October 1893, p. 7.

19. Boston Globe, 8 October 1893, p. I.

20. Samuel Gompers to AFL Executive Council, 5 February 1894, in Stuart B. Kaufman and Peter J. Albert (eds), The Samuel Gompers Papers vol. 3: Unrest and Depression, I89I-94 (Urbana, IL, 1989), p. 460. The $L E J$ reported Auburn shoe factories to be operating at two-thirds of their capacity as of early January, 1894. United States Bureau of Labor, Tenth Annual Report of the Commissioner of Labor, vol. 1: Strikes and Lockouts (Washington DC, 1896) (hereafter referred to as Strikes and Lockouts), reported I,106 new workers in the factories as of I January 1894. 21. Pray, Small and Co. was still on the "We Don't Patronize" list in the American Federationist, vol. 2, no. 6, August 1895 . 
other serial/serial possibilities. A second strike narrative, that of male mule spinners and their female co-workers in New Jersey during the winter of I890/91, highlights the ways in which ethnicity and gender could at times overlay and reinforce each other. ${ }^{22}$ As in the boot and shoe industry, workers in thread factories such as Clark's ONT Thread Company of Newark and Kearney faced a sexual division of labor that made them highly interdependent. Female carders and framers prepared raw materials for spinning. Mule spinners and their assistants, all male, then worked the cotton into yarn. Female workers applied themselves to more mechanized ring spinning, turning the men's yarn into fine thread. Though the sexes worked in completely separate workrooms - and even buildings - within the factory complex, the labor of both sexes was required for the completion of the work. If one group stopped production, the other usually had to follow suit in short order.

Within this sexual division of labor, workers at the New Jersey thread mills found themselves divided along ethnic lines as well. While the male workers in the mills were mainly Protestants from "north country" England and Scotland, the young female workers were overwhelmingly Irish and first-generation Irish-American Catholics. ${ }^{23}$ Furthermore, the history of the male mule spinners' union, the National Cotton Mule Spinners' Association (NCMSA), was also firmly tied to the migration of Lancashire immigrants to New England. ${ }^{24}$ Both occupationally and organizationally, ethnicity and gender operated in tandem in the New Jersey mills. This dual functioning of series memberships plays a key role in our strike narrative, almost overdetermining that the proud mule spinners would make the condescending statements about and dismissive actions toward their female co-workers which occurred in the course of the strike.

Members of the series, mule spinners at the Clark thread mills, held a number of complaints against their employer by the winter of $1890 / 91$. Their wages had decreased in recent months and they also decried abusive treatment by the mills' superintendent, Herbert Walmsley. On Saturday, 6 December 1890 , Walmsley fired one of the company's older spinners. Forty of his fellow spinners in one of the mills left their work the following Monday in protest. In response, Walmsley "told the men that if they did not

22. Unless otherwise noted, this strike story is taken from the New York Times (hereafter cited as $N Y T$ ) and the Newark Daily Advertiser (hereafter cited as NDA).

23. US Department of the Interior, Census Office, Report on Population of the United States at the Eleventh Census: 1890, Pt. II (Washington DC, 1897), pp. 698-699; Fourth Annual Report of the Commissioner of Labor, I888: Working Women in Large Cities (Washington DC, 1889), pp. 236, 274-275. The statistics in these sources also indicate a large number of German male workers among the "cotton, woolen, and other textile mill operatives", but Clark's was known for hiring "Scotch or North country Englishmen". See The New York Daily Graphic, 25 January I888, p. 617. 24. See Mary H. Blewett, "Deference and Defiance: Labor Politics and the Meaning of Masculinity in the Mid-Nineteenth-Century New England Textile Industry", Gender \& History, 5 (1993), pp. $398-415$. 
like his management they could put on their coats and leave, and refused to treat with the men". ${ }^{25}$ Spinners in the company's other two mills met and voted to quit work as well. By I p.m. all I20 spinners at Clark's chose not to return to their work. Since the spinners were no longer at work, a number of their co-workers - both male and female - also found themselves out of work.

On Tuesday, out of the mills' approximately 2,000 employees, 800 (reportedly all men) stayed away from work, closing the spinning departments of all three mills. At a meeting that morning, strikers "decided not to go back to work again till they [were] assured of satisfactory treatment" ${ }^{26}$ At the end of the workday, mill management announced that all departments would close for an indefinite length of time. The New York Times reported that: "The I,200 or I,500 girls who were thrown out of employment at the time when they most need money, and when misery becomes more miserable without it, were disheartened by the turn of affairs, and some of them showed their disappointment in their tears. ${ }^{27}$ For the women of the Clarks' mills, recognition of their series membership came with the hardship of unemployment.

The Clarks attempted to reopen their mills the following Tuesday, but none of their employees responded to the call to return to work. Some of the young women, however, were expected "to return to their benches" to finish work which they had left uncompleted at the time of the strike/ shutdown. One of the spinners told the New York Times that "his bell is constantly ringing to admit young girls who come to plead with him to make a speedy settlement of the troubles" ${ }^{28}$

On Saturday strikers arrived at the mill offices to collect their final pay checks. Eight men, local leaders of the spinners' union, were told that their services were no longer needed. Arguing that the firm was attempting to destroy their union, the fired men once again spoke out against "the most unjust and tyrannical oppression ever imposed upon us by one of the most obnoxious Superintendents ever imported from Russia or elsewhere to this beloved country of ours". ${ }^{29}$ Though it is unclear whether Walmsley actually came from Russia, the use of this accusation, with its overtones of the known brutality of the Russian tsar, was a way for the spinners to reinforce their own ethnic heritage as "free Britons".

Following strict craft union principles, money from the spinners' national union would go only to the mule spinners and the boy piecers and creelers who worked under them. The strikers' acknowledgment of their fellow 
workers combined a mix of solidarity, condescension, and indifference. "Of course," commented one spinner to the New York Times,

[...] we fell [sic] with the 2,700 operatives who are not organized, and who will not receive any pecuniary assistance. We'll do what we can to help the boys and girls who have widowed mothers or others who cannot help themselves depending upon them by organizing entertainments. But the shut-down will not drive us from our purposes. ${ }^{30}$

As Christmas approached, efforts to solicit additional financial contributions for the strikers and their supporters increased. Women workers went doorto-door and one local saloon keeper offered to contribute all of his Christmas earnings to the relief fund. New York city and national unions were also approached for support. These various fund-raising efforts were soon embroiled in controversy, however, as out-of-work women claimed that they did not receive any of the funds from the various benefits. Late December Newark newspaper accounts repeatedly discussed the "considerable feeling among the thread mill girls" about the "efforts for relief made in their behalf by the public" and from which they received little benefit. ${ }^{31}$

The irony here is that the non-union funds appear to have been solicited largely by the women themselves or through appealing to the public's sympathy for the women. For example, in January, with the beginning of scab production in the mills, the New York Central Labor Union called for a boycott of the mills' products. The Executive Council of the AFL nationalized this boycott in early February, using Walmsley's abusive treatment of women workers as the most prominent example of the "system of tyranny and persecution" at Clarks' ONT Thread mills. ${ }^{32}$

At the end of December, the Clarks began to import yarn from their Scottish mills. They claimed that they did this because of the public outcry over the condition of the mills' women workers thrown out of work by the mule spinners' strike. As one newspaper reporter put it, "The girls wanted to stand by the spinners, but the wolf was growling outside the door, so they had to bury their wishes and return to work. ${ }^{33}$ The women worked for three days on the imported yarn, but were told on New Year's Eve that the mills would close until the first Monday of the new year. Monday 5 January, described by a Newark reporter as "a cold bitter morning", witnessed a "touching scene" at the mill gates, as several hundred women

30. $N Y T$, in December 1890, p. 2. This statement also implies that there were important divisions by age as well as by sex and ethnicity in the mills.

31. NDA, 27 December I890, p. I, and 26 December I890, p. I.

32. SG to AFL Executive Council, 4 February I89I, Samuel Gompers Letterbooks, microfilm reel 4, vol. 5, frame 408; SG to Henry A. Woods, Kearney, NJ, 5 February 1891, reel 4, vol. 5, frame 413. AFL's boycott circular found in The Tailor, 2.20 (April 1891), p. 6. Most of the comments about Walmsley's treatment of women referred back to an I888 strike of women workers at the mills. See The New York Daily Graphic, 25 January 1888, p. 614.

33. $N Y T, 4$ January 189i, p. 16. 
workers gathered to plead for their jobs back. Many told observers that the "scanty assistance" received from the relief funds forced them to return to work, even if, as rumored, they would be working with imported strikebreakers. ${ }^{34}$

Through this first week of January, the Clarks did in fact begin to recruit strikebreakers aggressively. News reports said that the Clarks especially sought Canadian spinners from other textile centers. The company also began to stock the mills with food and sleeping supplies. Striking spinners scoffed at the idea of the mill hiring Canadian spinners, pointing out that "on a former occasion Superintendent Walmsley had said he would never again employ a down-east spinner, as there had always been trouble with those who came from Canada. He said that the Canadian spinners are not competent men and are little, if any, better than the piecers who are employed in the Clark mills." 35

Despite strikers' disdain and picketers' efforts to prevent the introduction of strikebreakers, production resumed in some mill departments in January. The Clarks announced that once the initial spinning was underway, other workers would be reemployed and more departments would reopen. The introduction of strikebreakers escalated the strike, as mill management had apparently known that it would. The weekend before the mills reopened, the Clarks had requested further police protection for their property, though the mule spinners scoffed at the company's fears, stating that "they neither contemplate violence nor will countenance it if it be attempted".${ }^{36}$ Nevertheless, intermittent violence marked the strike throughout the rest of January and February.

Striking spinners continued to deny their participation in violent outbreaks, largely through claims to their heritage as responsible employees and union men. As the company intermittently opened various mill departments, female employees faced difficult decisions. Should they accept employment alongside strikebreakers in order to gain much-needed wages? Or should they support the striking mule spinners and refuse to work on "scab products"? Despite the fact that the mule spinners had shown little support for the women thus far, over the remaining months of the strike women workers in the mills decided to walk out from their jobs a surprising number of times. Though it is difficult to understand where the women's sense of solidarity came from, given the deep divide between them and the male strikers, at least some of it was rooted in the main focus of the male spinners' cause: the women's old nemesis, Herbert Walmsley. When it became clear in March that Walmsley would remain as the mills' superintendent, over 100 women decided to quit work, arguing that "their earnings

34. $N D A$, s January I891, p. I.

35. Ibid.

36. NYT, i2 January i 89 I, p. 2. 
had been so miserably small since the strike as not to tempt them to handle material prepared for them by scab' hands [...]. [T] here was to be no escape from Walmsley, and they could not reconcile themselves to the idea of permanent servitude to such a boss. ${ }^{n 7}$ The women's interests in the strike were therefore simultaneously financial, solidaristic, and selfish. The women workers' identifications as members of different series would lead them to alternately join the male spinners' strike and to resume work.

The strike at Clarks' mills ended officially in April, when Massachusetts state senator and long-time NCMSA leader, Robert Howard, negotiated with the Clarks the terms for the mule spinners' return to work. The New York Times reported that: "[E]ven Superintendent Walmsley has agreed to make things as comfortable as he can for [the men who are taken back]. ${ }^{{ }^{38}}$ Just as the spinners' union had ignored the financial needs of the unorganized female workers throughout the strike, the strike's settlement ignored them as well. The women of the Clarks' mills would remain aware of their own series memberships if only because their co-workers refused to acknowledge their existence.

In this strike, gender and ethnicity were so closely identified with each other that it is virtually impossible to untangle the identifications out of which workers acted. It was apparently also impossible for the workers themselves to untangle these, as attempts to join together in any sort of class-based action failed repeatedly. With the mule spinners' union so deeply embedded in traditions of immigration from Scotland and northern England, the spinners repeatedly dismissed the concerns of the mostly Irish and Catholic female workers laid off by the cessation of production in the mills. The women workers' identifications as members of various series (women workers, laid-off workers, non-union members, Irish Catholics) came close to congealing into group identities at points, only to be ripped apart by the impact of financial need or the mule spinners' stronger organization.

\section{I}

Jewish garment workers in 1892 Baltimore, Maryland, generated yet another series of ethnic, gender, and class identifications. ${ }^{39}$ Their strike demonstrates the ways in which cross-class ethnic ties could be torn asunder by crossgender class consciousness, which was then further reinforced by the appearance of an ethnic "other". Institutional rivalries compound this story. The workers in this strike, mostly recent Jewish immigrants from Poland, labored in the sweatshops of Jewish coat tailors who contracted to supply 
coats to various clothing wholesalers. As in the other strikes examined, the Baltimore garment workers' work process also entailed a definite sexual division of labor. Employed directly by the wholesalers, Lithuanian men worked as cutters. Coat pieces were then sent to individual shops for construction by the "Hebrew" workers there. As the Maryland Bureau of Industrial Statistics described it, "[i]n most of the coat tailors' shops the employees work in teams, comprising an operator, whose work is upon a sewing machine, a baster, a presser and several girls".$^{\circ}$

The Polish Jews in the coat sweatshops had initially formed local assemblies of the Knights of Labor, but in I89I switched their allegiance to the AFL's United Garment Workers of America (UGWA). In the late spring of 1892, these workers attempted to negotiate standard terms of employment with their bosses, eventually sparking a strike.

On 23 June the workers' union submitted a list of demands to their employers, asking for a uniform ten-hour day, regular payment of wages, signing of a union contract, and acceptance of a system of "walking delegates" allowed to enter each shop at regular intervals. At this point, the action against the "sweaters", as their bosses were called, was fairly disorganized. What historian Susan Glenn has called "the familial tone of the workroom life in these ghetto shops ${ }^{n},{ }^{4 x}$ complicated presentation of the demands. Sharing religious, ethnic, and geographic ties with their immigrant employers inhibited workers from taking the firm action required so as to make their demands stick. The employers assured workers that they would discuss the demands at the end of the week. At this point, workers' identifications as union members battled with their membership in the series, Polish-immigrant Jews, a membership shared with employers.

The arrival in town of Henry Reichers, secretary of the UGW, began to change this paralysis. Since Reichers did not share workers' ethnic identification with the coat contractors, he moved to put the strike on more formal footing. Acting on Reichers' advice, members of the two union locals involved pre-empted their employers' offers of negotiations and voted to strike as of Thursday 30 June. Almost a thousand workers walked out that day against some thirty-four contractors. During the first few days of the strike, contractors mainly seemed panicked over what they interpreted as demands for higher wages and the abolition of piece work. Many argued that they could not sign a union contract, since they could not be sure of having consistent work throughout the year. The union also asked contractors to post a $\$ 500$ bond to ensure that workers received their pay, and some of the contractors balked at that, possibly because they simply could not come up with the money.

40. Maryland, Bureau of Industrial Statistics, Second Annual Report of the Bureau of Industrial Statistics of Maryland, (Baltimore, MD, 1894), p. 8I.

41. Susan A. Glenn, Daughters of the Shtetl: Life and Labor in the Immigrant Generation (Ithaca, NY, 1990), p. 134 . 
Over the next several weeks, a number of contractors gave in to the workers' demands, and by the end of the first full week of July over a third of the contractors had signed, providing work for some of the strikers. These expressed satisfaction with the new working conditions, and one even told the Baltimore newspaper "that the contractor for whom he worked had expressed regret that the system had not been adopted long ago".42 Over the next few weeks some of the city's wholesale clothing houses also asked the contractors who worked for them to sign the union agreement.

At this point in the strike attempts were made to have the situation submitted to a bilateral committee for "arbitration". On II July the contractors' organization, the Monumental Tailors' Beneficial Association (MTBA), held a long discussion of arbitration and ultimately voted unanimously to attempt it. For the next six weeks strikers and contractors experimented with many different committee permutations for arbitration.

Though the local paper hardly mentions the women involved in this strike, they apparently took an active role. The "women's branch", Local 33, solicited financial support for the strike, and also received sisterly support from the "Women's Branch of the Garment Workers' Union in New York". The secretary of Local 33, "Miss Cilea Grott", told the Sun "that the woman workers were making a firm stand and were no less determined than the men". ${ }^{43}$

The union women's decision "not to work as finishers on garments made by non-union workmen" as well as the agreement by many of them "to remain on strike without drawing benefits from the union" paid off in the last week of July. ${ }^{44}$ When the arbitration committee met on 27 July the contractors' representatives attempted to divide the strikers along gender lines, suggesting that women employees not be required to belong to the union. Male union representatives rejected this suggestion, arguing that "the girls had stood by them during the strike and the male members of the union would look after them". ${ }^{45}$ Local 26 's membership the next night ratified this immediate reaction from the UGW's all-male arbitration committee, when "the men [...] voted to stand by the girls" ${ }^{46}$ Faced with this resolve, the contractors made no further efforts to divide the strikers by gender. In this case, ethnic ties shared among the workers operated against the contractors. Appealed to on the basis of their membership in gendered series, neither the men nor the women allowed themselves to be used against the other group.

Yet another development underscored how common ethnic bonds among the men and women on strike contributed to ensuring their continued

42. Sun, 9 July I892, p. 8.

43. Sun, 16 July 1892, p. 8.

44. Sun, 20 July I892, p. 8.

45. Sun, 28 July I892, p. 8.

46. Sun, 29 July 1892 , p. 8. 
solidarity. At the July in meeting of the MTBA, local leaders of the Knights of Labor had spoken strongly in favor of arbitration. While this first participation in the strike by the Knights was positive, the Knights fairly quickly took a number of stands which transformed the strike into "a clean cut [fight] between the Federation and the Knights".${ }^{47}$ Already by i2 July the Knights' District Master Workman was claiming that all the clothing cutters in Baltimore belonged to the Clothing Cutters' and Trimmers' Assembly No. 7507, and using that information to urge the wholesalers to pressure contractors not to sign the UGW's agreement. Several divisions other than the organizational one made the continuing distinction between garment workers (in the UGW) and clothing cutters (in the Knights of Labor) especially salient. Clothing cutters worked in the shops of the contracting wholesalers, not in the sweatshops of the coat tailors. In addition, the cutters organized by the Knights in Baltimore were largely Lithuanians, so they did not share the ethnic bonds of the Polish-Jewish garment workers. These distinctions underlay the division of workers in the Baltimore industry into opposing union organizations. Later in the strike, the striking sweatshop operators would themselves join the Knights of Labor, forming the "Monumental Coat Contractors' Assembly" of that organization.

Over the ensuing months the conflicts brought to light by the original strikers in Baltimore would be played out on the organizational level, telling us much more about the dying Knights of Labor and the growing American Federation of Labor than about the identifications of the workers themselves. Before becoming bogged down in these organizational battles, though, the Baltimore strike demonstrated yet another way in which gender, ethnicity, and class might be played out in a volatile strike situation. While Baltimore garment workers refused to let their bosses divide them along gender lines, the organizations of the workers divided them along ethnic lines. The mixed responses of the boss "sweaters" to the strike demands may very well have resulted from conflicting ethnic and economic pulls on the coat tailors. While their common ethnicity encouraged some to sign the Garment Workers' agreement, economic necessity motivated others to do whatever was necessary to stay in the good favor of the wholesalers who kept them in business and with whom they had few ethnic ties.

\section{IV}

Ethnic discord might be expected in our final example since many ethnic as well as gender and organizational differences divided the workforce. But in this strike we find no discord whatsoever. The several hundred employees of the Wilkes-Barre, PA, Lace Manufacturing Company in 1902 belonged to five separate craft unions and encompassed (in descending order of 
representation) workers of Irish, German, English, native-born American, Welsh, Scottish, Polish, Austrian, French, Swedish, Swiss, Danish, BritishCanadian, French-Canadian, and Hungarian descent. ${ }^{48}$ Here, too, a sexual division of labor ensured that occupational distinctions separated most men and women at the workplace. Though this strike, too, ultimately ended in failure (workers returning to work on management's terms), it illustrates the type of situation in which incipient ethnic rivalries could be overcome by shared family ties with larger contextual events.

The famous anthracite coal strike of 1902 was just over a month old when it propelled men and women employed by the Wilkes-Barre Lace Company into a strike of their own. ${ }^{49}$ In the midst of the fiercely-fought coal strike, the lace strike began when members of the lace workers' unions approached five female workers who had relatives still at work in local coal mines. The lace workers gave these co-workers a choice of either quitting their jobs or having their relatives quit working in the mines. When the women refused or were unable - to do either, the lace unions approached mill management and asked that they be fired. On Tuesday 17 June mill manager J. W. Doran announced that he would not fire the girls. In response, the lace workers' unions voted to strike. At a joint meeting of the Cotton Workers' Union \#8957, Lace Finishers' \#8948, Lace Menders' \#8151, Brass Bobbin Workers' \#8628, and Lace Weavers' Branch No. 2, workers voted to remain on strike until the issue was resolved.

The family ties of the lace workers appear to have both initiated their strike and overcome their ethnic differences. Almost a third (thirty-two per cent) of the lace workers lived with at least one coal mine worker in their household. Women were more likely than men were to live with a coal miner; forty-one per cent of the women and only eighteen per cent of the men did. Younger lace workers were also more likely to reside with coal miners than were older lace workers. For example, forty-four per cent of women between fifteen and nineteen years old and twenty-nine per cent of men in that age group lived with a miner. Not surprisingly, most of the miners were the fathers or brothers of these lace workers, which helps explain why the lace workers would have found it difficult to convince the miners in their families to change their strategies regarding the coal strike. ${ }^{50}$ Ethnic differences in the presence or absence of miners in lace workers'

48. Unless otherwise noted, the story of this strike is taken from the American Wool o Cotton Reporter, vol. 16, and the Wilkes-Barre Times (hereafter cited as WBT). Information on the workers' ethnicity and households comes from the 1900 Manuscript Census for Wilkes-Barre, PA. The list of ethnicities includes both immigrants from the country indicated and those who could be identified as having parents or grandparents from the given country.

49. R. Fillipelli (ed.), Labor Conflict in the United States: An Encyclopedia (New York and London, 1990), pp. 17-19.

5o. Of the women who lived with miners, forty-seven per cent lived with a coal-mining brother and fifty-seven per cent had coal-mining fathers. 
households appear to have been insignificant. The lace workers' comprehension of coal miners' solidarity and the symbolic reach of that solidarity into their own work lives therefore grew out of very personal familial ties.

Lace mill management must have found it difficult to understand why their workers felt so strongly about an issue which seemingly had nothing to do with their own work. At the same time, the workers' demand that the "girls" be fired went against all concepts of management's right to make hiring and firing decisions. The result appears to have been to create two unmoveable parties to the situation. Lace workers would not end their support of the coal strike; management would not give up their workplace control. The third party to the situation, the workers' national union, had its own views of the strike. One can only imagine the consternation of the executive board of the "National Amalgamated Association of Lace Workers" when they heard of the Wilkes-Barre strike. The board, based in Philadelphia, disapproved of the Wilkes-Barre strike, believing in both arbitration and prior strike approval by the board.

The resulting mixed feelings of the executive board were apparently communicated when manager Doran met with the board on July 5 in a conference which officially ended without any agreement. Within a week, mill management announced that they would reopen the mills, reserving for themselves the right to "employ or discharge" employees and to make decisions on promotions and mill rules. They further required that workers acknowledge overseers' judgements on the allotment of work and submit any complaints only to the mill management. Striking mill workers met over the weekend, voted not to accept management's conditions, and therefore did not return to work the following Monday. Without workers, production could not resume. As the Wilkes-Barre paper put it, "It is now likely that this fight between the management and the strikers will be one to a finish." ${ }^{\text {"r }}$

Almost a month later, a conference between Doran and a committee of the strikers settled the strike. At this point, strikers agreed to virtually all of Doran's conditions, with the addition of an arbitration procedure, as urged by the union's national executive board. On Monday II August work resumed in the mill. The Wilkes-Barre paper reported that "Apparently the strikers were pleased that the difficulty is settled and naturally all were in good humor." ${ }^{\text {p2 }}$

The brief narrative of this strike provides few of the identification shifts seen in previous strikes. Despite the consternation of the workers' national union, the Wilkes-Barre lace workers remained unwavering in their identification as supporters of the coal miners' strike. Membership in neither their ethnic nor their gender series rose to supplant this identification. Instead, 
workers' familial connections to the massive 1902 anthracite coal strike remained paramount throughout the lace strike. Series identification arose more from workers' experiences beyond their workplace than from those within the workplace.

\section{$\mathrm{V}$}

The strikes narrated in this paper have illustrated different ways in which individuals' recognition of ethnic identity could interact with their recognition of gender and class identities. In each strike workers' identities developed along with the serial narrative of the particular strike situation. The use of Sartre's concept of the series helps us think about the many possible variations of class, ethnicity, and gender. Though Sartre planned to use his concept of series as a way to examine peoples' class identities, my employment of the concept broadens it to include other categories of identification as well. Using the concept this broadly highlights the importance of three key issues: historical narrative, historical materialism, and the agency of individuals and groups within both of those. In each of the strikes retold here, individuals act out of identities formed by both specific material circumstances and specific events. By thinking of these identities as representative of memberships in different series we keep alive the possibilities of change inherent in individuals' lives. Each individual has at her disposal an array of experiences from which she can and must construct her own responses to the events in which she finds herself. Thinking of these experiences as the formative materials of membership in different series aids the historian in thinking about class, gender, ethnicity, race, and other categories less as one-time choices of identity made by individuals and more as part of an array of choices out of which individuals act.

The shoe workers of Auburn, Maine, the thread workers of Newark and Kearney, the Baltimore garment workers, and the Wilkes-Barre lace workers all brought a range of options with them into their workplaces and therefore into their strikes. At times viewing themselves as women or men, skilled workers or unskilled workers, members of one ethnic group or another, members of families, or simply as strikers, workers in these strikes (just as workers in contemporary strikes) highlight the interactions of ethnicity, gender, and class. They remind us that the members of the working class are always also members of many other series, any one of which may reinforce or undermine their class identity and consciousness during the course of living, that is, of creating historical narrative. 